\title{
PENGARUH CURRENT RATIO, RETURN ON ASSET DAN PRICE EARNING RATIO TERHADAP HARGA SAHAM PT.KALBE FARMA Tbk
}

\author{
Nur Puji Astuti *) \\ *) Mahasiswa Program Studi Manajemen FE UNKRIS \\ Alamat: Kampus UNKRIS, Jatiwaringin Jakarta Timur
}

\begin{abstract}
Abstrct: This type of research uses quantitative research. The data source of this research is secondary data. The data analysis method used is the correlation test, determination test, multiple linear regression test and hypothesis testing, namely the f test and t test. The results of this study indicate that the Current Ratio, Return on Assets, and Price Earning Ratio simultaneously have a significant effect on stock prices. Partially Current Ratio and Return on Asset have no significant effect, while Price Earning Ratio partially has a significant effect on the stock price of PT Kalbe Farma Tbk. To obtain this data, researchers used the website of PT Kalbe Farma Tbk, and the Indonesia Stock Exchange (IDX).
\end{abstract}

\section{Keywords: Current ratio, return on asset dan price earning ratio dan harga saham}

\section{PENDAHULUAN}

Pasar Modal memiliki peranan penting dalam perekonomian suatu Negara karena pasar modal dapat menjalankan dua peranan, yaitu sebagai sarana pendananaan usaha atau tempat untuk mendapatkan modal dari investor, dan dana yang diperoleh bisa digunakan untuk pengembangan perusahaan atau penambahan modal kerja dan lain-lain. Pasar modal adalah salah satu cara untuk berinvestasi yang diminati oleh para investor di Indonesia.

Investasi saham pada pasar modal memiliki daya tarik tersendiri bagi investor, karena saham mampu memberikan tingkat keuntungan yang sangat menarik. Keuntungan dalam investasi saham pada perusahaan yang sudah go public, yaitu dividen dan capital gain. Dividen pada umumnya dibagikan kepada pemilik saham atas persetujuan pemegang saham atas, yang diperoleh dari keuntungan yang dihasilkan oleh perusahaan tersebut.Capital gain diperoleh dari selisih positif antara harga jual saham dengan harga beli saham.

Harga saham merupakan faktor yang sangat penting serta yang harus diperhatikan oleh para investor dalam melakukan investasi karena harga saham sangat menentukan prestasi emiten. Jika emiten memiliki prestasi yang baik maka keuntungan yang didapat dari hasil operasi usaha semakin besar. Dengan demikian harga saham emiten yang bersangkutan akan naik. Harga yang terlalu rendah juga sering diartikan bahwa kinerja perusahaan kurang baik. Jika harga saham sangat tinggi dapat mengurangi kemampuan investor untuk membeli saham sehingga menimbulkan harga saham sulit untuk meningkat kembali.

Dalam penelitian ini, penulis menggunakan perusahaan yang bergerak dibidang farmasi yang merupakan bagian dari perusahaan manufaktur. Salah satu sektor yang terdaftar di Bursa Efek Indonesia adalah sektor farmasi. Karena sektor Farmasi memiliki peran dalam reformasi dalam bidang kesehatan. Kebutuhan obat-obatan yang meningkat 
seiring dengan bertambahnya populasi penduduk dapat memberikan peluang bagi industri farmasi untuk berkembang.

Permasalahan kesehatan yang terjadi pada umumnya sangat berkaitan dengan ketersediannya obat-obatan yang dibutuhkan oleh masyarakat. Kesadaran terhadap kesehatan pada masyarakat Indonesia adalah menjadi pendorong meningkatnya konsumsi obat-obatan. Dalam hal ini menyebabkan varietas produk yang dihasilkan oleh industri farmasi semakin bertambah tidak hanya obat-obatan yang dikonsumsi untuk dapat menyembuhkan penyakit namun juga ada suplemen makanan sebagai salah satu upaya preventif dalam peningkatan kualitas kesehatan.

Pertumbuhan pasar farmasi di Indonesia cenderung menunjukkan peningkatan. Tercatat pada pertumbuhan pasar farmasi pada tahun 2013 hingga 2017 yang terus meningkat.

Tabel 1: Daftar Jumlah Penduduk dan Pertumbuhan Pasar Industri Farmasi di Indonesia periode $2013-2017$

\begin{tabular}{ccc}
\hline Tahun & Jumlah Penduduk & Pasar Farmasi (Triliun) \\
\hline 2013 & 249,9 Juta & 17,76 \\
2014 & 253,6 Juta & 29,22 \\
2015 & 254,9 Juta & 23,00 \\
2016 & 257,9 Juta & 70,00 \\
2017 & 262,4 Juta & 72,00 \\
\hline
\end{tabular}

Sumber: Badan Pusat Statistik dan Indonesian Pharmacommunity

Penanaman modal dalam Negeri (PMDN) dari tahun 2013 hingga 2017 mengalami peningkatan yang signifikan, yaitu senilai mencapai 33,695 Triliun. Pada tahun 2014 di Indonesia terdapat 206 perusahaan pelaku industri farmasi yang mana 33 perusahaan diantaranya merupakan penanam modal asing (PMA) (Bisnis.com, 2014). Sedangkan perusahaan farmasi yang terdaftar pada Bursa Efek Indonesia adalah 9 perusahaan.

Indonsia merupakan pasar farmasi yang dapat menjanjikan dibandingkan dengan negara lain di Asia Teggara. Terdapat beberapa faktor yang dijadikan driver dalam pertumbuhan industri farmasi yang ada di Indonesia yaitu meningkatnya jumlah penduduk yang besar, masyarakat yang memiliki kesadaran tinggi akan kesehatan, meningkatnya perekonomian masyarakat dan menigkatnaya akses kesehatan.

Berdasarkan informasi yang diperoleh dari Tim Nasional Percepatan Penanggulangan Kemiskinan (TNP2K) beberapa macam bentuk jaminan kesehatan sebelum JKN merupakan bagian dari Sistem Jaminan Sosial Nasional (SJSN) yang sudah diimplementasikan pemerintah. Hal ini tertuang dalam UU No 40 tahun 2004. Pada program tersebut antara lain meliputi Askes Sosial untuk Pegawai Negeri Sipil dan penerima pensiun \& veteran, Jaminan Pemeliharaan Kesehatan (JPK) Jamsostek bagi pegawai BUMN dan swasta, serta jaminan kesehatan untuk TNI dan Polri. Kemudian pada tahun 2005 kementrian kesehatan melaksanakan program Jaminan Pemeliharaan Kesehatan bagi masyarakat Miskin (JPKMM) atau yang dikenal dengan nama Askeskin (Asuransi Kesehatan bagi Masyarakat Miskin).

Namun pada tahun 2008 hingga 2013, program tersebut sudah berubah menjadi Program Jaminan Kesehatan Masyarakat (Jamkesmas). Dengan diimplementasikannya Jaminan Kesehatan Nasional pada 1 Januari 2014, jadi semua program jaminan kesehatan diintegrasikan pada satu Badan Penyelenggara Jaminan Sosial (BPJS) Kesehatan. Program ini menyediakan bantuan Iuran bagi masyarakat tidak mampu yang terdaftar sebagai peserta penerima bantuan Iuran (Tim Nasional Percepatan Penanggulangan Kemiskinan (TNP2K), 
2017). Maka dengan adanya program tersebut, permintaan terhadap obat pun meningkat dan sangat memicu pertumbuhan penjualan obat.

Berdasarkan data yang diperoleh tersebut, bahwa data menunjukkan dengan bertambahnya jumlah penduduk Indonesia setiap tahunnya diikuti dengan bertambahnya jumlah penjualan dari industri farmasi. Maka dapat disimpulkan bahwa bertambahnya penduduk di Indonesia akan memberikan dampak pada bertambahnya penjualan dari industri farmasi, hal ini dikarenakan dengan besarnya jumlah penduduk suatu negara maka akan semakin besar juga kebutuhan obat-obatan yang dikosumsi oleh penduduk di negara tersebut.

Regulasi sudah menjadi faktor pasti yang berdampak pada lingkup bisnis sebuah industri.Hal yang terjadi ketika pemerintahan Indonesia memberlakukan regulasi terkait dengan Jaminan Sosial, yaitu Badan Penyelenggara Jaminan Sosial (BPJS).Khusus nya BPJS Kesehatan, pengaruh dari regulasi ini sangat dirasakan oleh para pelaku bisnis farmasi. Dengan adanya regulasi tersebut, maka produksi obat-obatan oleh industri farmasi akan meningkat karena bertambah nya konsumen.

Dalam persaingan yang ketat ini perusahaan -perusahaan farmasi yang terus berusaha mengembangkan produknya sangat memerlukan pendanaan yang besar. Sumber pendanaan perusahaan terbagi menjadi dua yaitu sumber dari Internal dan eksternal perusahaan. Sumber dana dari internal perusahaan yaitu diperoleh dari laba ditahan (retained earning) dan depresiasi, sedangkan sumber dana eksternal diperoleh dari modal saham (equity) dan pinjaman atau hutang.

Modal saham adalah investasi yang diperoleh dari investor yang membeli saham di pasar modal. Investor memilih untuk membeli saham investasi saham dengan pertimbangan tingkat pengembalian atas dana yang mereka investasikan dalam bentuk dividen atau selisih dari harga beli dengan harga jual (capital gain). Penilaian saham yang potensial juga harus dilakukan secara cermat. Karena sesuai dengan prinsip investasi pasar modal adalah "Low risk low return, high risk high return" yaitu resiko yang kecil akan memberikan tingkat keuntungan yang kecil dan resiko yang besar akan memberikan tingkat keuntungan yang besar.

Dengan demikian para investor memerlukan berbagai informasi untuk dijadikan pedoman dalam memutuskan investasi dipasar modal karena untuk menguranggi ketidakpastian dalam mendaptkan keuntungan dan resiko yang besar akan memberikan keuntungan yang besar. Sebelum melakukan jual beli saham para investor akan melakukan analisis sekuritas untuk mengetahui apakah saham yang akan dibeli dapat memberikan keuntungan bagi para investor atau justru sebaliknya yang akan merugi. Untuk dapat menganalisis harga saham dan memilih saham terdapat tiga pendekatan yaitu analisis teknikal, analisis fundamental, analisis informasional.

Dalam melakukan penelitian ini penulis menggunakan penelitian pendekatan analisis fundamental untuk memprediksi harga saham, Jika suatu perusahaan tersebut menghasilkan laba yang besar, maka pembagian deviden kepada pemegang saham akan mendapatkan besar juga. Dengan tingginya deviden yang dibagikan kepada pemegang saham akan berpengaruh terhadap harga saham yang ada di pasar saham.

Komaruddin (2004) analisis fundamental adalah "suatu pendekatan untuk menghitung nilai intrinstik saham biasa (common stock) dengan menggunakan data keuangan perusahaan". Setiap perusahaan yang sudah go public akan mempublikasikan laporan keuangan pada setiap periode untuk memberikan informasi kepada pihak-pihak yang berkepentingan seperti manager, pemerintah, investor dan lain sebagainya. Bagi investor laporan keungan sangat penting untuk menganalisis saham yang akan dibeli dengan menggunakan pendekatan fundamental. Ratio keuangan yang digunakan untuk mengukur 
dan menganalisis kinerja keuangan sebuah perusahaan terbagi menjadi lima kelompok yaitu ratio liquiditas, solvabilitas, profitabilitas, aktivitas dan nilai pasar.

Current ratio (CR) merupaka ukuran yang digunakan untuk mengetahui kesanggupan perusahaan untuk memenuhi kewajiban jangka pendek, karena ratio ini menunjukkan seberapa jauh tuntutan dari kreditur jangka pendek dapat dipenuhi oleh aktiva yang diperkirakan menjadi uang tunai dalam periode yang sama dengan jatuh tempo hutang (Sawir, 2005). Yang berarti, semakin tinggi tingkat current ratio maka akan memberi pengaruh baik terhadap kinerja keuangan perusahaan dan sebaliknya. Dalam penelitian ini current ratio karena tinggkat liquiditas perusahaan sangat diperhatikan oleh para investor, liquiditas perusahaan dalam jangka pendek yang tinggi akan memberikan keyakinan kepada investor terhadap kemampuan perusahaan untuk membayarkan dividen.

Return on asset (ROA) mengukur seberapa baik manajemen tersebut menggunakan semua aktiva untuk menghasilkan keuntungan atau laba. Ratio ini yang menggabungkan antara laba sebelum pajak dengan total aktiva. Karena itu, semakin besar ROA perusahaan, semakin besar pula tingkat keuntungan yang dicapai oleh perusahaan tersebut (Fakhruddin dan Hardianto, 2001). Dalam penelitian ini return on asset dipilih untuk mewakili ratio profitabilitas, karena ROA dapat membantu perusahaan yang telah menjalankan praktik akuntansi dengan baik untuk dapat mengukur efisiensi penggunaan modal yang menyeluruh, yang sensitif terhadap setiap hal yang mempengarui keadaan keuangan perusahaan sehingga dapat diketahui posisi perusahaan terhadap industri.

Price Earning Ratio (PER) merupakan perbandingan antara harga pasar dengan net income per lembar saham. Karena ukuran tersebut menyangkut suatu jumlah yang tidak dapat dikendalikan secara langsung oleh perusahaan, sehingga PER merupakan indikator terbaik bagi investor untuk memperkirakan kinerja keuangan pada perusahaan diamasa yang akan datang (Munawir, 2008).

Tujuan penelitian ini adalah untuk menganlisis pengaruh current ratio, return on asset dan price earning ratio terhadap harga saham PT. Kalbe Farma Tbk.

\section{LANDASAN TEORI}

\section{Current Ratio}

Current ratio merupakan ratio likuiditas yang membandingkan antara aktiva lancar dengan hutang lancar jangka pendek. Menurut Husnan (2004) Current ratio merupakan ratio anatara aktiva lancar dengan hutang lancar yang dimiliki oleh perusahaan, ratio ini mengukur aktiva lancar yang dimiliki oleh perusahaan dalam menjamin hutang lancar perusahaan. Menurut Sutrisno (2009) Current ratio adalah rasio keuangan yang membandingkan antara aktiva lancar yang dimiliki perusahaan dengan hutang jangka pendek. Dalam aktiva lancar meliputi kas, piutang dagang, persediaan. Sedangkan hutang jangka pendek meliputi hutang dagang, hutang wesel, hutang bank, hutang gaji dan hutang lainnya yang harus segera dibayar. Menurut Harahap (2010) ratio lancar yang menunjukan sejauh mana aktiva lancar menutupi kewajiban - kewajiban lancar. Apabila ratio ini $1: 1$ atau 100\% maka berarti bahwa altiva lancar dapat menutupi semua hutang lancar. Menurut Brigham dan Houston (2010) Current ratio merupakan rasio lancar untuk mengukur kemampuan aktiva lancar dalam membayar hutang lancar. Aktiva lancar biasanya terdiri dari: Kas, surat berharga, piutang dan persediaan. Hutang lancar terdiri dari hutang dagang, wesel bayar jangka pendek, hutang jangka panjang yang segera jatuh tempo, pajak yang belum dibayar (accued) dan biaya-biaya yang belum dibayar (accrued) lainnya (terutama upah).

Dengan demikian dapat disimpulkan bahwa current ratio yang tinggi menunjukkan bahwa perusahaan mampu memenuhi kewajiban atau hutang jangka pendek dengan 
menggunakan asset lancarnya, sehingga dari sisi para pemegang saham memiliki kepercayaan yang kuat terhadap kemampuan perusahaan yang memiliki tingkat current ratio yang tinggi. Menurut Pengukuran ratio Liquiditas pada penelitian ini dapat dilakukan dengan menilai ratio lancar (current ratio).

$$
\text { Current Ratio }=\frac{\text { Current Assets }}{\text { Current Liabilities }} \times 100 \%
$$

\section{Return On Asset}

Return on asset bertujuan untuk mengukur efektivitas perusahaan dalam menghasilkan keuntungan dengan memanfaatkan aktivitas yang dimikinya. Menurut Brigham dan Houston (2010), Return on asset merupakan ratio untuk mengukur tingkat pengembalian aktiva. Ratio inidapat dihitung dengan membandingkan laba setelah beban bunga dan pajak dengan total aktiva. Menurut Kasmir (2010) Return on asset merupakan ratio yang menunjukkan hasil (return) atas jumlah aktiva yang telah digunakan dalam perusahaan. Dengan demikian dapat dikatakan bahwa jika suatu perusahaan memiliki tingkat return on assset yang tinggi akan menarik minat investor untuk dapat menanamkan modalnya pada perusahaan tersebut. Karena perusahaan tersebut dapat menghasilkan laba yang tinggi dan memberikan dampak yang positif pada nilai deviden yang akan diterima oleh para investor.

Dengan banyaknya investor yang tertarik untuk membeli saham perusahaan maka akan berpengaruh juga terhadap harga saham di pasar modal. Dan semakin banyak para investor yang membeli saham perusahaan tersebut maka harga saham perusahaan tersebut akan cenderung mengalami kenaikan.

$$
\text { Return on Asset }=\frac{\text { Net Incomes }}{\text { Total Assets }} \times 100 \%
$$

\section{Price Earning Ratio}

Price earning ratio merupakan hubungan antara harga di pasar saham dengan earning per share saat ini yang digunakan secara luas oleh investor sebagai perpaduan umum untuk mengukur nilai saham. Price earning ratio yang menunjukkan seberapa besar keuntungan yang diperoleh pemegang saham pada per lembar saham.

Menurut Jogiyanto (2008) price earning ratio merupakan rasio yang menunjukkan ratio dari harga saham terhadap earnig. Rasio ini menunjukkan seberapa besar investor menilai harga dari saham terhadap kelipatan dari price earning ratio yang tinggi menunjukkan bahwa para investor bersedia untuk membayar dengan harga saham premium atau dengan harga diatas harga pasar yang ada. Menurut Brigham \& Houston (2010) Price earning ratio merupakan ratio harga persaham terhadap laba per saham menunjukkan jumlah yang rela dibayarkan oleh investor untuk setiap rupiah laba yang dilaporkan. Price earning ratio mengukur bagaimana investor menilai prospek pertumbuhan dimasa yang akan datang, dan tercermin pada harga saham yang bersedia dibayar oleh investor untuk setiap rupiah laba yang diperoleh perusahaan. Semakin tinggi ratio ini maka menunjukkan bahwa investor mempunyai harapan yang baik tentang perkembangan perusahaan dimasa yang akan datang, sehingga untuk pendapatan per saham tertentu, investor bersedia membayar dengan harga yang mahal (Sudana, 2011).

Price earning ratio adalah indikator berapa besar nilai (value) yang diapresiasi oleh investor terhadap nilai perusahaan price earning ratio bermanfaat untuk melihat bagaimana pasar menghargai kinerja saham suatu perusahaan terhadap kinerja perusahaan yang tercermin dalam laba perusahaan (Prihadi, 2013). Ratio ini dapat dihitung dengan rumus : 


$$
\text { PER }=\frac{\text { Harga per Lembar saham (Current Price) }}{\text { Laba per lembar saham }(E P S)}
$$

\section{Harga Saham}

Menurut Darmaji dan Fakharuddin (2011) saham merupakan sebagian tanda penyertaan atau pemilikan seseorang atau badan dalam suatu perusahaan. Menurut Gitman (2007) saham adalah bentuk paling murni kepemilikan perusahaan. Menurut Sunariyah (2011) yang dimaksud dengan saham adalah surat berharga yang dikeluarkan oleh sebuah perusahaan yang berbentuk perseroan Terbatas (PT) atau yang biasa disebut dengan emiten.

Saham adalah tanda penyertaan atau pemilikan seseorang atau badan dalam suatu perusahaan atau perseroan terbatas (Hendy, 2010). Porsi kepemilikan saham ditentukan oleh seberapa besar penyertaan yang ditanamkan pada perusahaan tersebut. Saham merupakan tanda bukti penyertaan kepemilikan modal atau dana pada suatu perusahaan (Fahmi, 2012:81). Dengan memiliki saham pada suatu perusahaan maka investor akan memiliki hak terhadap pendapatan dan kekayaan yang ada pada suatu perusahaan. Semakin besar suatu saham dimilikinya, maka semakin besar pula kekuasannya di dalam perusahaan tersebut. Keuntungan yang diperoleh dari saham dikenal dengan nama Deviden. Pembagian deviden diatur dalam ketentuan Rapat Umum Pemegang Saham (RUPS).

Menurut Kasmir (2010) saham dapat dibagi menjadi dua kelompok yaitu: 1). Dari Segi Cara Peralihan: a). Saham atas unjuk (bearer stocks), merupakan saham yang tidak mempunyai nama atau tidak tertulis nama pemilik dalam saham tersebut. Saham jenis ini sangat mudah untuk dialihkan atau dijual kepada pihak lain. b). Saham atas nama (registered stocks), merupakan saham yang tertulis nama pemiliknya dan untuk dialihkan kepada pihak lain diperlukan syarat dan prosedur yang tertentu. 2). Dari Segi Hak Tagih: a). Saham biasa (common stocks), bagi pemilik saham ini hak untuk memperoleh deviden tidak diuatamakan, karena deviden akan didahulukan kepada saham preferen. Dan begitu pula hak terhadap harta apabila perusahaan di liquidasi. b). Saham preferen (prefered stocks), merupakan saham yang para pemiliknya memperoleh hak utama dalam deviden dan harta apabila pada saat perusahaan diliquidasi.

Menurut Jogiyanto (2008) terdapat beberapa hal bagi pemegang saham biasa, anatara lain: 1). Hak Menerima Pembagian Keuntungan. 2). Hak untuk memperoleh laba dari perusahaan dalam bentuk deviden yang dibagikan oleh perusahaan. Hak untuk menerima pembagian aktiva perusahaan dalam hal perusahaan di liquidasi. 3). Hak kontrol; Hak untuk berpartisipasi dalam menentukan arah dan tujuan perusahaan yaitu melalui hak suara dalam rapat pemegang saham. 4). Hak preventif; Hak untuk membeli saham baru yang dikeluarkan perusahaan agar proporsi pemilikan saham masing -masing pemegang saham tidak berubah.

Terdapat beberapa Keuntungan dan Kerugian dalam kepemilikan saham diantaranya: 1). Keuntungan kepemilikan saham; a). Investasi saham yang cukup liquid dan mudah dipindah tangankan, mudah diperjual belikan dengan biaya transaksi yang relatif rendah. $b$ ). Peluang memperoleh dengan hasil yang cukup besar berupa capital gain karena saham berperan dalam laba perusahaan. c). Unit biaya saham biasanya cukup rendah sehingga terjangkau oleh investor. 2). Kerugian kepemilikan saham; a). Resiko yang cukup tinggi berupa resiko bisnis, resiko finansial dan risiko pasar yang berpengaruh negatif terhadap deviden. b). Kesulitan menilai dan memilih saham yang berprestasi dimasa yang akan datang.

Faktor yang mempengaruhi pergerakan saham menurut Brigham dan Houston. (2010) adalah proyeksi laba per lembar saham saat diperoleh laba, proporsi utang perusahaan terhadap equitas serta kebijakan dalam pembagian deviden. Menurut Sawidji (2002) Faktor 
utama yang menyebabkan harga saham adalah persepsi yang berbeda dari masing-masing investor sesuai dengan informasi yang sudah diperoleh.

\section{METODE PENELITIAN}

Data yang digunakan dalam penelitian ini adalah data sekunder yaitu berupa data yang sudah diolah oleh perusahaan dan disetujui oleh akuntan publik independen, yang berupa laporan keuangan setiap kuartal dari kuartal pertama tahun 2013 sampai dengan kuartal ke empat tahun 2017 yang di publikasikan dalam website BI (www.bi.go.id). Harga saham periode tahun 2013-2017 yang digunakan adalah harga saham penutupan tanggal laporan keuangan setiap kuartal yang di publikasikan dan diperoleh dari website Bursa Efek Indonesia (www.idx.co.id) .

Dalam penelitian ini peneliti menggunakan metode kuantitatif dengan menggunakan regresi kinier berganda dan sederhana.

\section{HASIL PENELITIAN DAN PEMBAHASAN}

\section{Hasil Penelitian}

\section{Analisis regresi berganda}

Tabel 1: Pengaruh Current Ratio, Return on Assets dan Price earning Ratio terhadap Harga Saham PT. Kalbe Farma Rbk

\begin{tabular}{|c|c|c|c|c|c|}
\hline \multirow[b]{2}{*}{ Variabel } & \multicolumn{5}{|c|}{ Parameter } \\
\hline & R Square & Konstanta & $\begin{array}{c}\text { Koef. } \\
\text { Regresi }\end{array}$ & Sig. & $\alpha$ \\
\hline Current ratio & & & 0.071 & 0.119 & \\
\hline Return on assets & 0.458 & 6.331 & -0.007 & 0.250 & 0.05 \\
\hline Price earning ratio & & & 0.021 & 0.003 & \\
\hline
\end{tabular}

Pengujian Signifikansi

F hitung $>\mathrm{F}$ tabel $=4.499>3.239$

Sumber: data diolah 2020

Persamaan regresi linear: $\mathrm{Y}=6,331+0,071 \mathrm{X}_{1}-0,007 \mathrm{X}_{2}+0,021 \mathrm{X}_{3}$

Berdasarkan Tabel 1, nilai $\mathrm{F}$ hitung sebesar 4,499. menunjukkan bahwa secara bersama-sama current ratio, return on assets dan price earning ratio berpengaruh signifikan terhadap harga saham PT.Kalbe Farma,Tbk. Nilai koefisien determinasi ( $R$ Square) adalah sebesar 0,458 atau $45,8 \%$. Hasil ini menunjukkan bahwa current ratio, return on assets dan price earning ratio kepada harga saham PT.Kalbe Farma,Tbk adalah sebesar 45,8\%, dan sisanya sebesar $54,2 \%$ dijelaskan oleh variabel lainnya dan tidak dimasukkan kedalam model regresi dalam penelitian ini.

Current ratio, return on assets dan price earning ratio berpengaruh tidak signifikan terhadap harga saham PT.Kalbe Farma,Tbk. Nilai koefisien regresi current ratio bertanda positif sebesar 0,071, yang maknanya, jika current ratio mengalami kenaikkan, maka harga saham semakin meningkat atau sebaliknya dengan asumsi return on assets dan price earning ratio tidak berubah. Nilai koefisien regresi return on assets bertanda negatif sebesar $-0,007$, yang maknanya, jika return on assets mengalami kenaikkan, maka harga saham akan menurun atau sebaliknya dengan asumsi current ratio dan price earning ratio tidak berubah. 
Nilai koefisien regresi price earning ratio bertanda positif sebesar 0,021, yang maknanya, jika price earning ratio mengalami kenaikkan, maka harga saham akan meningkat atau sebaliknya dengan asumsi current ratio dan return on assets tidak berubah.

\section{Analisis regresi sederhana}

Tabel 2: Pengaruh Current Ratio terhadap Harga Saham PT. Kalbe Farma Rbk

\begin{tabular}{lccccc}
\hline \multirow{2}{*}{ Variabel } & \multicolumn{6}{c}{ Parameter } \\
\cline { 2 - 6 } & $\begin{array}{c}\text { Square } \\
\text { Current ratio }\end{array}$ & Konstanta & $\begin{array}{c}\text { Koefisien } \\
\text { Regresi }\end{array}$ & Sig & $\boldsymbol{\alpha}$ \\
\hline Pengujian Signifikan & 0,026 & 7,142 & 0,037 & 0,495 & 0.05 \\
\hline t hitung $>$ t tabel $=0.696>2.101$ & & & & \\
\hline Sumber: Data primer, diolah, 2020 & & & & & \\
\hline
\end{tabular}

Persamaan regresi $\mathrm{Y}=7,142+0,037 \mathrm{X}_{1}$

Berdasarkan Tabel-2, nilai koefisien determinasi $\left(\mathrm{R}^{2}\right)$ sebesar 0.026 , artinya current ratio memberikan kontribusi sebesar 2,6\% kepada harga saham PT. Kalbe Farma,Tbk, sedangkan sisanya sebesar $97,4 \%$ disumbangkan faktor lain yang tidak diteliti. Current ratio berpengaruh positif dan tidak signifikan pada tingkat nyata 99\% terhadap harga saham PT. Kalbe Farma,Tbk. Koefisien current ratio bertanda positif sebesar 0,037, artinya jika ada kenaikkan current ratio, maka harga saham PT. Kalbe Farma,Tbk akan meningkat atau sebaliknya.

Tabel 3: Pengaruh Return on Asset terhadap Harga Saham PT. Kalbe Farma Rbk

\begin{tabular}{lccccc}
\hline \multirow{2}{*}{ Variabel } & $\begin{array}{c}\mathbf{R} \\
\text { Square }\end{array}$ & Konstanta & $\begin{array}{c}\text { Koefisien } \\
\text { Regresi }\end{array}$ & Sig & $\boldsymbol{\alpha}$ \\
\hline Return on Asset & 0,025 & 7,361 & $-0,005$ & 0,501 & 0.05 \\
\hline Pengujian Signifikan & & & & & \\
\hline t hitung $>\mathrm{t}$ tabel $=-0.686>2.101$ & & & & \\
\hline
\end{tabular}

Sumber: Data primer, diolah, 2020

Persamaan regresi $\mathrm{Y}=7,361-0,005 \mathrm{X}_{2}$

Berdasarkan Tabel 3, nilai koefisien determinasi $\left(\mathrm{R}^{2}\right)$ sebesar 0.025 , artinya return on asset memberikan kontribusi sebesar 2,5\% kepada harga saham PT. Kalbe Farma,Tbk, sedangkan sisanya sebesar 97,5\% disumbangkan faktor lain yang tidak diteliti. Return on asset berpengaruh positif dan tidak signifikan pada tingkat nyata $99 \%$ terhadap harga saham PT. Kalbe Farma,Tbk. Koefisien return on asset bertanda negatif sebesar -0,005, artinya jika ada kenaikkan return on asset, maka harga saham PT. Kalbe Farma,Tbk akan mengalami penurunan atau sebaliknya.

Tabel 4: Pengaruh Price earning Ratio terhadap Harga Saham PT. Kalbe Farma Rbk

\begin{tabular}{|c|c|c|c|c|c|}
\hline \multirow[b]{2}{*}{ Variabel } & \multicolumn{5}{|c|}{ Parameter } \\
\hline & $\begin{array}{c}\mathbf{R} \\
\text { Square }\end{array}$ & Konstanta & $\begin{array}{c}\text { Koefisien } \\
\text { Regresi }\end{array}$ & Sig & $\alpha$ \\
\hline Price earning ratio & 0,333 & 6,662 & 0,019 & 0,008 & 0.05 \\
\hline
\end{tabular}


$\mathrm{t}$ hitung $>\mathrm{t}$ tabel $=2.999>2.101$

Sumber: Data primer, diolah, 2020

Persamaan regresi $\mathrm{Y}=6,662+0,019 \mathrm{X}_{3}$

Berdasarkan Tabel 4, nilai koefisien determinasi $\left(\mathrm{R}^{2}\right)$ sebesar 0.333 , artinya price earning ratio memberikan kontribusi sebesar 33,3\% kepada harga saham PT. Kalbe Farma,Tbk, sedangkan sisanya sebesar 66,7\% disumbangkan faktor lain yang tidak diteliti. Price earning ratio berpengaruh positif dan signifikan pada tingkat nyata $99 \%$ terhadap harga saham PT. Kalbe Farma,Tbk. Koefisien price earning ratio bertanda positif sebesar 0,019, artinya jika ada kenaikkan price earning ratio, maka harga saham PT. Kalbe Farma,Tbk akan meningkat atau sebaliknya.

\section{Pembahasan}

\section{Pengaruh Current Ratio, Return on Asset dan Price earning Ratio secara simultan Terhadap Harga Saham}

Current ratio, return on asset dan Price earning Ratio mendukung peningkatan harga saham, salah satu faktor meningkat nya harga saham pada PT.Kalbe Farma,Tbk pada tahun 2015 adalah dengan adanya program pemerintah yaitu BPJS Kesehatan. hal tersebut yang menjaikan harga saham naik dan memberikan dampak positif untuk perusahaan karena akan semakin banyak invetor yang berkeinginan untuk berinvestasi, sehingga harga saham menjadi naik.

\section{Pengaruh Current Ratio Terhadap Harga Saham}

Hasil penelitian menunjukkan bahwa current ratio mendorong peningkatan harga saham. Hal ini didukung oleh penelitian Subarjo (2015) yang menyatakan bahwa current ratio tidak berpengaruh secara signifikan terhadap harga saham namun koefisien bernilai positif. Dalam perkembangan sistem keuangan mulai direspon oleh perusahaan-perusahaan go public, yang termasuk dalam pengelolaan harta lancar. Current ratio yang rendah biasanya menunjukkan adanya masalah dalam liquiditas perusahaan. Karena Current ratio yang rendah akan menurunkan harga saham perusahaan yang bersangkutan dan investor akan memilih saham perusahaan yang yang memiliki liquiditas yang tinggi. Current ratio yang terlalu tinggi juga belum tentu menunjukkan perusahaan dalam kondisi yang baik, hal ini dapat dikarenakan kemungkinan terdapat banyak dana perusahaan yang tidak berputar, dengan kata lain dapat diartikan terjadi penurunan pada produktivitas perusahaan kerena adanya aktivitas menurun dan pada akirnya akan mengurangi pendapatan perusahaan. Jadi tidak ada ketentuan yang mutlak tentang tingkat current ratio pada suatu perusahaan yang dianggap baik atau harus dipertimbangkan oleh perusahaan, karena yang bergantung pada jenis usaha, cash flow suatu perusahaan. Dalam hal ini penilaian pada harga saham melalui tingkat current ratio suatu perusahaan bukan merupakan satu-satunya ratio yang mempengaruhi pada harga saham perusahaan, karena masih ada ratio liquiditas lainnya yang memberikan pengaruh terhadap kinerja keuangan suatu perusahaan dan pada akirnya akan memberikan pengaruh pada harga saham.

\section{Pengaruh Return on Asset Terhadap Harga Saham}

Return on asset tidak mendotong peningkatan harga saham, ini bertentangan dengan penelitian yang dilakukan oleh Subarjo (2015) dan Lauda (2018) yang menyatakan bahwa return on asset adalah variabel yang berpengaruh positif dan signifikan terhadap harga saham. 


\section{Pengaruh Price earning Ratio Terhadap Harga Saham}

Price earning ratio mendorong peningkatan harga saham. Hal ini sesuai dengan hipotesis yang telah dibangun dimana price earning ratio akan berpengaruh signifikan terhadap harga saham dan konsisten pada penelitian Rahmadewi \& Abundanti (2016) serta Lauda (2018) yang menyimpulkan bahwa price earning ratio berpengaruh secara signifikan terhadap harga saham.

\section{KESIMPULAN DAN SARAN}

\section{Kesimpulan}

Berdasarkan hasil penelitian yang telah dilakukan oleh peneliti maka dapat diambil disimpulan sebagai berikut: 1). Current ratio, return on asset dan price earning ratio mendorong peningkatan harga saham. Rasio keuangan yang digunakan dalam penelitian ini dapat membantu investor dalam melakukan pengambilan keputusan untuk berinvestasi dalam jangka panjang agar mendapatkan keuntungan. 2). Current ratio mendorong peningkatan harga saham. 3). Return on asset tidak mendorong peningkatan harga saham. Dilihat berdasarkan nilai return on asset yang diperoleh dapat menunjukkan bahwa investor tidak memperhatikan laporan pada kinerja keuangan perusahaan, dan hanya melihat keuntungan dari capital gain atau selisih harga jual dan harga beli yang terjadi pada pasar modal. Investor ini merupakan investor jangka pendek. 3). Secara parsial variabel price earning ratio berpengaruh positif dan berpengaruh signifikan terhadap harga saham. Karena semakin besar PER, maka perusahaan tersebut memiliki laba bersih yang prospektif sehingga investor akan tertarik untuk berinvestasi karena adanya peningkatan harga saham perusahaan di pasar modal. Dan PER yang tinggi menunjukkan bahwa perusahaan menjalankan perusahaanya dengan baik.

\section{Saran}

Berdasarkan hasil penelitian yang telah dilakukan dalam penelitian ini, maka berikut saran dari peneliti: 1). Bagi Investor; Para Investor dapat memperhatikan variabel CR, ROA dan PER secara simultan ketika akan berinvestasi saham. Dan dalam pengambilan keputusan tidak hanya memperhatikan laporan keungan namun faktor-fakor lainnya yang menyebabkan penagaruh erhadap harga saham. 2). Bagi Emiten; Emiten lebih meningkatkan kembali kinerja keuangan perusahaan dengan lebih memperhatikan CR,ROA dan PER serta ratio keuangan lainnya dengan tujuan untuk memaksimalkan nilai kekayaan pada shareholder. 3). Bagi Peneliti Selanjutnya; Peneliti selanjutnya bisa mengembangkan dengan menambahkan jumlah data variabel yang diteliti sehingga hasil yang diperoleh lebih dapat mencerminkan kondisi yang sebenarnya di Bursa Efek Indonesia.

\section{DAFTAR PUSTAKA}

Brigham dan Houston. 2010. Dasar - Dasar Manajemen Keuangan. Jakarta: Penerbit Salemba Empat.

Darmaji dan Fakharuddin. 2011. Pasar Modal di Indonesia (edisi 3). Jakarta: Salemba Empat.

Fakhruddin dan Hardianto. 2001. Pasar Modal di Indonesia. Jakarta: Salemba Empat. Gitman. 2007. Principles Of Managerial Finance (13th Editi). United States: Pearson Education. 
Harahap, Sofyan Syafri. 2010. analisis krisis atas laporan keuangan. Jakarta: Rajawali Persada.

Hendy. 2010. Dasar - dasar Pembelajaran Perusahaan. Yogyakarta: BPFE.

Husnan, Suad. 2004. Dasar-Dasar Manajemen Keuangan (Edisi keem). Yogyakarta: UPP AMP YKPN.

Jogiyanto. 2008. Teori Portofolio dan Analisis Investasi (Edisi Kedu). Yogyakarta: BPFE.

Kasmir. 2010. Pengantar Manajemen Keuangan. Jakarta: Kencana Prenada Media Group.

Komaruddin. 2004. Dasar-Dasar Manajemen Investasi dan Portofolio (Edisi Revi). Jakarta: PT. Rineka Cipta. Adiwiratama.

Lauda (2018) yang berjudul "Pengaruh Return On Asset, Debt to Equity, Earning Per Share dan Economic value added Terhadap Harga saham pada Industri dasar dan Kimia".

Munawir. 2008. Analisis Laporan Keuangan. Jakarta: Liberty.

Prihadi. 2013. Analisis Laporan Keuangan Lanjutan Proyeksi dan Valuasi. Jakarta: PPM.

Rahmadewi, P. W., \& Abundanti, N. 2018. Pengaruh Eps , Per , Cr , Dan Roe Terhadap Harga Saham Di Bursa Efek Indonesia. E-Jurnal Manajemen Unud, 7(4), 2106-2133. https://doi.org/https://doi.org/10.24843/EJMUNUD.2018.v7.i04.p14 ISSN.

Sawidji. 2002. Cara Sehat Investasi di Pasar Modal. Jakarta: PT Jurnalida Aksara Grafika.

Sawir. 2005. Analisis Kinerja Keuangan dan Perencanaan Keuangan. Jakarta: PT. Gramedia Pustaka Utama.

Subarjo. 2015. Pengaruh Return On Asset (ROA), Current Ratio (CR), Net Profit Margin (NPM) Dan Inflasi Terhadap Harga Saham (Studi Kasus PT Kalbe Farma Tbk Periode Tahun 2001 - 2014). Fakultas Ekonomi Universitas Mercu Buana Yogyakarta, IV(2), $50-66$.

Sudana. (011. Manajemen Keuangan Perusahaan. Jakarta: Erlangga.

Sunariyah. 2011. Pengantar Pengetahuan Pasar Modal. Edisi Keenam. Yogyakarta: UPP STIM YKPN.

Sutrisno. 2009. Manajemen Keuangan Teori, Konsep dan Aplikasi. Edisi Pertama, Cetakan Ketujuh. Yogyakarta: Penerbit Ekonisia.

Tandelilin, Eduardus. 2010. Portofolio dan Investasi. Yogyakarta: Kanisius.

Sumber dari website:

http://www.kalbe.co.id

http://www.idx.co.id

http://www.badanpusatstatistik.co.id 